\author{
Comparative Education
}

\title{
Beyond internationalisation and isomorphism - the construction of a global higher education regime
}

\author{
Mike Zapp \& Francisco O. Ramirez
}

To cite this article: Mike Zapp \& Francisco O. Ramirez (2019): Beyond internationalisation and isomorphism - the construction of a global higher education regime, Comparative Education, DOI: $\underline{10.1080 / 03050068.2019 .1638103}$

To link to this article: https://doi.org/10.1080/03050068.2019.1638103

Published online: 08 Jul 2019.

Submit your article to this journal $\pi$

View Crossmark data $\asymp$ 


\title{
Beyond internationalisation and isomorphism - the construction of a global higher education regime
}

\author{
Mike Zapp ${ }^{\mathrm{a}}$ and Francisco O. Ramirez \\ aniversity of Luxembourg, Institute of Education and Society, Luxembourg, Luxembourg; ${ }^{\text {bS Stanford }}$ \\ University, Stanford, CA, USA
}

\begin{abstract}
National higher education systems are undergoing profound changes, discussed in many but unrelated studies as outcomes of internationalisation dynamics and institutional isomorphism pressures. We propose to link these studies by emphasising the influence of both internationalisation and isomorphism on the formation of a global educational regime. Through a broad range of indicators, we describe the growth of the discursive, normative, and regulatory dimensions of such a global higher education regime. We find evidence of the following developments: (1) a rapidly growing network of international organisations focused on conferences, initiatives, and programmes supporting a global higher education agenda; (2) a striking increase in the number of international and national accreditation agencies, their mutual cross-national recognition as well as the number of universities that are nationally and internationally accredited; and lastly, (3) parallel increases in regional qualification frameworks and in the implementation of national qualification frameworks. These developments create integration pressures manifest in the mutual recognition of higher education degrees, for which a new generation of regional conventions has emerged worldwide in the past two decades. We discuss these processes and their implications for understanding 'national' higher education as well as the threats and limits to the burgeoning higher education regime.
\end{abstract}

\section{KEYWORDS}

Higher education; internationalisation: isomorphism; integration; regime; quality assurance and accreditation; qualification frameworks; recognition

\section{Introduction}

National higher education systems around the world have seen profound institutional changes in the past two decades. One significant process involves increasingly mobile students and staff, programmes and campuses, embedded in a competitive environment and this process is commonly referred to as internationalisation (Knight 2014). A second development is the growing cross-national similarity in higher education discourses, policies, structures and curricula, usually captured by the concept of isomorphism (Meyer and Frank 2007).

Reviewing research on these major trends (Part 2), we find that while internationalisation scholarship recognises the lack of international governance structures to regulate national higher education fabrics (Dodds 2008; King, Marginson, and Naidoo 2011;

CONTACT Mike Zapp mike.zapp@uni.lu

(c) 2019 Informa UK Limited, trading as Taylor \& Francis Group 
Kosmützky and Putty 2016), it pays less attention to the recent emergence of actors, discourses, norms and regulations adding up to a new regime of quality assurance, accreditation, standardisation and recognition. Isomorphism research, while acknowledging the role of authoritative global models and IOs as their transmitters in the increasing similarity in higher education systems around the world, has shown less interest in the changing structure of the international organisational field in higher education (Anderson-Levitt 2012). By contrast, we understand (cross-) national permeability and similarity as necessary conditions for a burgeoning process of global higher educational integration. Integration, here, describes the process by which a set of novel, supranationally constructed, authoritative discourses, norms and rules increasingly complements and influences national higher education governance.

The idea of a 'global educational system' (Meyer 2006) has not received the attention it deserves. In a short reference to it, Meyer and Ramirez (2005) argue that such integration would require the mutual recognition of the structural or technical equivalence of national education systems. We will show that these arguments had anticipated what is indeed becoming a sweeping trend in the direction of a 'global higher education system', most clearly expressed in global discourses, networks, frameworks of quality assurance and accreditation (QAA) and the cross-national standardisation and recognition of degrees.

Instead of conceptualizing integration as a process leading to a single 'system' or 'society' of higher education systems, organisations or people, we focus on the integrative mechanisms and interacting actors involved in the construction of a global higher education regime. The regime concept (Krasner 1983) has never been empirically examined in the context of (higher) education, yet prior theoretical work suggests considerable analytical insight (Parreira do Amaral 2010). While higher education research is preoccupied with the increasingly strategic behaviour of higher education actors and their alliances, the regime concept drawn upon in this paper allows us to capture the discursive agenda formation and the emerging norms and regulations beyond universities. Thus, we stress the role of the highly diverse actors involved (from states and international organisations to QAA agencies). We argue that the construction of such a regime is facilitated both by the recent liberalisation and internationalisation wave in higher education and by the strong legitimacy of the university in the 'knowledge society' and the related isomorphic change in higher education systems around the world (Meyer and Frank 2007).

In Part 3, we specify ongoing discursive, normative and regulative processes of regime construction that transcend local-global and inter-state distinctions, thus, facilitating integrated 'oneness' beyond growing inter-national 'similarity'.

Among these, we identify a highly expansive network of international organisations (IOs) providing a discursive platform where a specifically 'global' higher education knowledge is produced, managed, exchanged and disseminated worldwide (Chabbott 2003; Zapp 2017). Using data from the International Congress Calendar published by the Union of International Associations (UIA), we use social network analysis to describe the organisational types and ties recently established around a growing number of substantive areas in this emerging global higher education discourse.

In the normative dimension, we point to the rise of national and international mechanisms of quality assurance and accreditation (QAA). Advanced by states, professional associations and international organisations as well as QAA agencies themselves, QAA is merging into a more unitary architecture for higher education institutions across sectors 
(public, for-profit and non-profit) and national systems. We trace the emergence of these national, regional and global QAA initiatives and present original data on international QAA organisations and the number of accredited universities worldwide.

A third, regulative process describes the beginning of a new era in efforts to standardise higher education qualifications internationally. Starting in the late 1990s, regional qualification frameworks (QFs) have proliferated globally. Coinciding with such international efforts, at the national level, our data show that the number of countries adopting QFs has massively increased by more than a hundred since 2006 .

These discursive, normative, and regulatory processes coincide with and culminate in the appearance of a new generation of strong and comprehensive regional recognition conventions. Finally, UNESCO is currently working on a Global Convention on the Recognition of Higher Education Qualifications. Such regional and global conventions will have important consequences for our conventional understanding of a 'national' higher education system.

This work seeks to add a novel perspective to global higher education developments. In this perspective, the focus lies with the complex multi-actor and multi-level architecture that re-embeds (once national, now increasingly autonomous and strategic) higher education institutions into international frameworks. These discursive, normative and regulative frameworks - provided they are not undermined by the recent wave of illiberal and nationalist ideology - might have the potential to provide an institutional corrective to an otherwise increasingly liberalized organisational field.

\section{Internationalisation and isomorphism in higher education}

In this section, we highlight internationalisation and isomorphism as two major transformations in higher education systems around the world. We argue that their analytical thrust has rarely been brought together. We do so by both extending the key arguments of both perspectives, highlighting their contribution in explaining a burgeoning process of global higher education integration.

\subsection{Internationalisation}

Systematically reviewing almost 2,000 publications from hundreds of journals in the field of international higher education (incl. transnational, off-shore, borderless higher education), Kosmützky and Putty (2016) sketch an expansive scholarship that sees higher education systems as under tremendous internationalisation pressures. With higher education and research internationalisation becoming an overriding policy priority around the world, decisions to open national borders and university doors, to liberalise trade and facilitate market access have changed national higher education sectors within two decades to a degree that not only challenges mainstream higher education research still anchored in national paradigms, but also the still small internationalisation scholarship to keep pace. As Knight (2014) stated, internationalisation has moved from people to programs to organisations and, additionally, entire systems. Consider the following trends: the most recent data on student mobility estimates the number of internationally mobile students to be at 5.1 million, while at just 2 million in 2000 (UIS 2018). The available data for offshore programs and teaching also show considerable increase. Within 6 years (1999-2005), 
Australian universities, for example, increased their offshore teaching programmes from 581 to 2,000, now serving 100,000 students outside of Australia (Chapman and Pyvis 2013). Turning our attention to joint programmes and joint/double degrees, data available for Europe, estimate the number of participations in joint programmes to be above 3,000 (European QA Register for Higher Education 2014). Open educational resources, massive open online courses and virtual universities have also skyrocketed around the world, with the latter teaching almost 11 million students. ${ }^{1}$ Further, the number of both public and private international branch campuses (IBC) has quintupled in the period 2000-15, with 311 IBCs from 40 countries now hosted by 90 countries around the world. ${ }^{2}$ At the level of entire systems, higher education is the most frequently included educational sub-sector in the General Agreement on Trade in Services, with currently 53 country commitments (WTO 2017).

Against the backdrop of thinning national borders, mobile students, staff, programmes and universities, concerns about quality assurance and accreditation (QAA) are the most frequently discussed issues in the field, especially in the context of the recent global privatisation boom (Levy 2006; Kinser et al. 2010). However, apart from a small number of contributions focusing on the European (Bollaert 2014; Kohoutek 2016), Asian (Hou 2012; Shin, Oh, and Moon 2016) and African (Watson 2009) regions, a thorough analysis of recent international and global processes in QAA is missing. Some of the few exceptions (Stella 2006; Hartmann 2007) predate the important events which we argue have brought about a new quality to global higher education governance.

Another central concern in the internationalisation debate is the (global) race for reputation, revenues and researchers that has gained momentum in the past two decades (Hazelkorn 2015; Brankovic 2018b). Situated in an increasingly global and competitive field, higher education institutions' research function has become the target of particular interest and policy directives such as national research evaluations and performancebased funding schemes (Hicks 2012). Importantly, national and international ratings and rankings (e.g. European 'Multi-Rank', and the global Academic Ranking of World Universities, to name a few) create new logics of quantification, comparison, distinction and stratification (Espeland and Sauder 2016).

Paradoxically, with competition grows collaboration. Regional associations (e.g. the European University Association) and more mission-led university alliances (e.g. the League of European Research Universities, or Universitas 21) have burgeoned everywhere in the past decade (Gunn and Mintrom 2013). The premium on excellence and selective networking have created new orders of stratification and fragmentation with universities as strategic actors constituting the central driving force (Ramirez and Tiplic 2014; Brankovic 2018a).

\subsection{Isomorphism}

While phenomena of internationalisation describe the increasing porosity of national higher education systems and the border-crossing activities of increasingly strategic higher education institutions, studies on cross-national isomorphism reveal growing similarity in higher education discourse, policy, structure and curriculum (Wiseman, Astiz, and Baker 2014). Worldwide, an instrumental discourse on science, the 'science for development policy model', has taken hold with higher education 
expansion being understood as a national, systemically planned, economically viable and utilitarian tool to foster progress (Drori et al. 2003). National policymakers, often supported by international organisations, have long regarded educational and scientific activity as a guarantor of national development (Finnemore 1993; Chabbott 2003; Hwang 2006). Such a view might help explain the worldwide proliferation of the university as the standard organisational form of educational and scientific activity (Riddle 1996). More recently, such an emphasis on national development has made way for prioritising global competitiveness in the knowledge economy (Buckner 2016). With states eliminating access barriers to higher education for specific groups (e.g. for women in science and engineering, see Ramirez and Wotipka 2001; for special education, see Powell 2016), enrolment has expanded remarkably. Schofer and Meyer (2005) show strikingly rapid and global growth in tertiary enrolment for the period after World War II, with enrolment expanding by factors 10-20. Less developed countries in Africa and Asia now have higher enrolment rates than core OECD countries like Germany or the United Kingdom 30 years ago.

Not only do national discourses, policies and expansion patterns converge globally, so do curriculum, teaching and research. Frank and Gabler (2006) chart the rise of the social sciences and the decline of the humanities in higher education curricula over the twentieth century. Bromley and Suarez (2012) trace the worldwide institutionalisation of human rights programmes at universities. Finally, Powell, Baker, and Fernandez (2017) gauge the global transformation of universities into research universities for the twentieth century.

Such isomorphism suggests the impact of globally diffusing models of state identity and higher education development institutionalised at the level of national policymaking. The elaboration and diffusion of such models has been facilitated by the growing importance of international organisations (IOs) in educational policymaking (Chabbott 2003; Zapp and Dahmen 2017). In this view, IOs come into play as 'teachers of norms' (Finnemore 1993), 'theorists' or 'rationalized others' (Meyer 1997), knowledge brokers and epistemic governance actors (Jakobi 2009; Zapp 2017), beyond hard governance instruments of funding and conditionality much discussed in the comparative education literature (see Zapp and Dahmen 2017 for a review). It is important to note the contribution of this strand of neo-institutional research by stressing the role of various regulative, normative and cognitive processes in shaping the order of the global higher education field and the behaviour of its actors. Such a lens brings the interplay of various actors (e.g. universities, supranational bodies, regional associations) at various levels to the fore of the analysis. Isomorphism and diffusion arguments provide a theoretical and methodological correction vis-à-vis an international higher education research field that still sees the nation-state as the locus classicus of higher education policy-making (Clark 1983; Enders 2004; Huisman, Meek, and Wood 2007; Bleiklie and Michelsen 2012; Kosmützky 2015). Conversely, much research on higher education internationalisation points to such important issues as quality assurance, accreditation and recognition that finds little interest in studies on the longue durée of higher education expansion and isomorphic change. We build on these literatures and contend that internationalisation and institutionalisation pave the way for an integrating global higher education regime. 


\section{Integration and regime construction in higher education}

Theoretically, we argue that both transformations, the increasing permeability of national higher education systems (internationalisation) and their increasing similarity (isomorphism), reinforce each other. Increasingly similar systems and regulatory frameworks (isomorphism) are likely to reduce uncertainty for higher education institutions and fan further cross-border activities (internationalisation) in the future, which will prompt calls for shared rules of the game. Open borders (internationalisation), in turn, suggest facilitated transfer and adoption of external higher education models and policies spurring further convergence (isomorphism). Yet, our point is that both processes cause a new phenomenon. We argue that both internationalisation and isomorphism facilitate the emergence of an overarching and integrating discursive, normative and regulative governance structure in higher education (Figure 1). We describe this structure with the notion of regime originally defined as 'implicit or explicit principles, norms, rules and decision-making procedures around which actors' expectations converge in a given area of international relations' (Krasner 1982, 186). Regimes do not emerge as ends in themselves but are created to provide collective problem-solving in specific issue areas and are based on knowledge and perceptions shared by their members.

The regime concept resonates with the idea of (global) organisational fields (DiMaggio and Powell 1983; Chabbott 2003), Dale's (2005) pluri-scalar governance in education and Mundy's (2007) educational multilateralism. It shares their agreement on the relevance of multiple actors (e.g. IGOs, INGOs, BINGOs, nation-states) at multiple levels with a shared (albeit not uncontested) definition of problem domains and issues. These are often perceived as too complex to be dealt with by any single actor (e.g. nation-state), but require collective engagement for the benefit of all involved (e.g. security, environment). For higher education, one of the most salient issue areas in the internationalisation literature is the concern about the quality of degrees, programmes, organisations and national systems in an internationalised higher education space marked by the growing mobility of people, programmes and organisations (Kosmützky and Putty 2016). We will see below in our network analysis that the number of actors and operational activities is, indeed, highest in this domain.

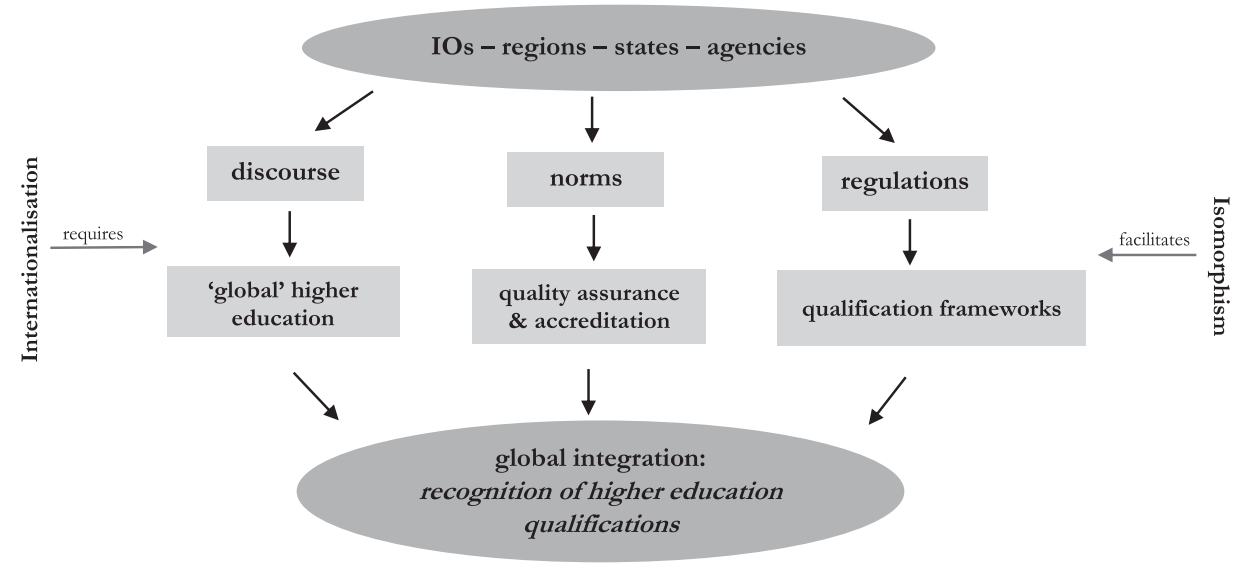

Figure 1. The construction of a global higher education regime. 
While scholarships on internationalisation and isomorphism usually focus on the analytical level of universities themselves, the regime concept directs attention to new modes of cooperation at multiple levels (e.g. sub-national, supranational, and international) and including multiple types of actors (e.g. governmental, non-governmental). The activities and goals of the regime - in higher education as in other fields - often involve the regulation of a global public good - in our case potentially countering the increasing privatisation and commodification of higher education (e.g. Verger 2009).

Exploring the regime concept for education in general, Parreira do Amaral (2010) distinguishes between international, transnational, governmental and non-governmental actors organised in an implicit or tacit regime, i.e. a regime characterised by a low degree of formal institutionalisation, but a high degree of convergence in expectations. Forums (e.g. Global Forum on Education), conferences (e.g. World Conference on Education), initiatives (e.g. EFA) and international comparative studies (e.g. PISA) are indicative of the increasing institutionalisation of education at the international level, even in the absence of any formal treaty (similar to the nuclear weapons regime, for example). Such a focus on the cognitive-cultural, communicative or discursive conditions of regime formation resonates with key tenets in institutional theory about the global diffusion and institutionalisation of universalised and highly legitimised scripts (see above; Meyer 1997; Drori et al. 2003).

Besides the distinction in tacit/implicit versus classic/explicit regimes, regimes can also be classified in terms of its development stage. Levy, Young, and Zürn (1995) distinguish between (1) agenda formation, (2) institutional choice and (3) operationalisation. The first stage, agenda formation, is reached once the issue has made its way into the policy agenda as a priority item. Institutional choice, then, implies that the involved actors officially agree on providing a regime, while specifying its substantive areas. Eventually, operationalisation means to transform agreements into 'functioning social practice' (Levy, Young, and Zürn 1995, 14) by establishing normative and regulative frameworks and organisational infrastructure to facilitate regime implementation.

Parreira do Amaral (2010) holds that the education regime has already reached the stage of institutional choice after several post-war decades during which the educational goals had been successfully established on the global political agenda. It would now be time to negotiate the contents of the agenda.

We will provide analyses that help identify the actors involved in regime construction, its degree of institutionalisation (tacit vs explicit) as well as its stage of development (from agenda formation to operationalisation) and agenda (content).

Figure 1 provides a heuristic for our analysis. In this framework, a wide range of actors engage in a discourse on the global dimension of higher education. Such a multi-level discourse translates into a set of norms and regulations in the specific areas of QAA, standardisation (qualification frameworks) and recognition - all facilitated by structural isomorphism in higher education and perceived by many as required in the face of growing internationalisation.

How does regime construction relate to integration? Regime construction has an integrating effect on higher education for two reasons: one structural, another substantive. Structurally, regimes, by definition, cross national legislative borders and establish shared sovereignties between various actors at multiple levels. Such a multi-actor constellation replaces traditional governance of higher education by creating common 
discourses, principles, norms and rules, leading to routinised interaction and cooperation. From an organisational perspective, it creates a common field level for the actual population affected by these changes, i.e. universities (DiMaggio and Powell 1983).

Another important integrating element is substantive, i.e. the agenda and themes dealt with in the regime. We will show that the current higher education regime agenda is, indeed, 'global', with three themes appearing as dominant. These revolve around issues of common standards for QAA, qualification frameworks and the recognition of qualifications. These themes are strongly interrelated and have emerged in conjuncture since the late 1990s, along with a novel set of actors, norms and rules. These themes, especially the recognition of qualifications, are in themselves integrating or cohesive in nature as they suggest increased awareness of equivalence among national higher education systems.

We now turn to the processes of regime construction in more detail.

\section{Processes of regime construction}

The following sections identify three recent trends that have the potential to alter national higher education systems and to facilitate their amalgamation. These trends reflect different kinds of institutional change processes including cultural-cognitive or discursive, normative and regulative processes. In particular, these trends reflect three different substantive issues. They include the emergence of a genuinely global higher education discourse supported by and reflected in densifying networks of international and national governmental and nongovernmental organisations and nation-states. They further include the emergence of a supranational QAA sector establishing novel global norms and standards as well as the proliferation of regulations setting global standards for qualifications and, related, for the recognition of higher education qualifications. We argue that these trends are conducive of regime construction and have the potential to cause lasting institutional change in higher education systems around the world, which we discuss below as higher educational integration.

\subsection{Discourse and networks}

International organisations have been shown to provide important discursive forums and nodes of diffusion for educational ideas (Jakobi 2012; Zapp and Dahmen 2017). We argue that prior to an analysis of the diffusion of specific ideas through IOs, we would need a more detailed picture of the changing scope and social structure of such a discourse. In line with Buckner (2016), we hold that higher education has emerged as a core feature of global discourse and that global discourse has likewise emerged as a core feature of national higher education policy. Ramirez, Meyer and Lerch (2016) have shown the striking increase in IOs, conferences, and publications related to higher education in the past two decades. The three UNESCO-led World Conferences on Higher Education $(1998 ; 2003 ; 2006)$ are prominent examples for such a novel interest at the international level.

The importance of certain key IOs (e.g. UNESCO, OECD, WB, EU) for primary and secondary education has been extensively discussed (Chabbott 2003; Bromley 2010; Zapp and Dahmen 2017); this paper seeks to ascertain whether a similarly expansive organisational 


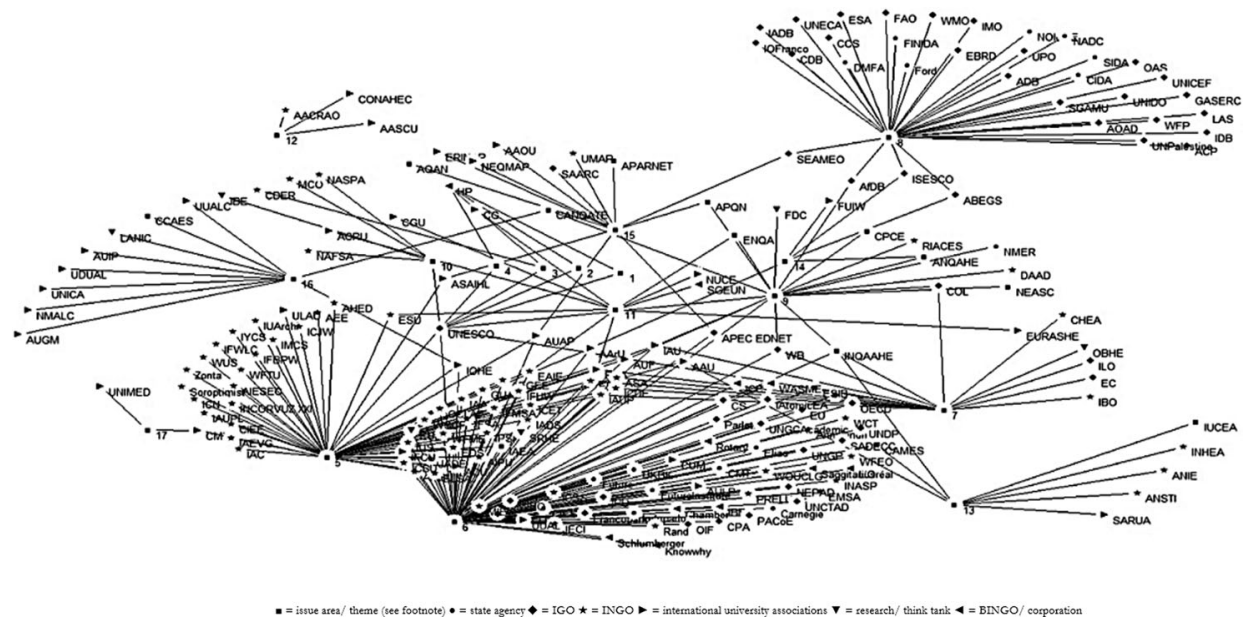

Figure 2. The global higher education governance network and its issue areas. Note: $1=$ Brain Gain Initiative; 2 = Brain Gain Initiative in African and Arab States; $3=$ Brain Gain Initiative African Pilot Project; $4=$ Brain Gain Initiative South-East Europe Project; $5=$ UNESCO/ NGO partnership: $6=$ UNESCO Forum on Higher Education, Research and Knowledge; $7=$ The Global Forum on International Quality Assurance and Accreditation; $8=$ General partnerships/ International University Cooperation; 9 $=$ Global Initiative for Quality Assurance Capacity; $10=$ general recognition; $11=$ recognition Europe; 12 = recognition North America; 13 = recognition Africa; $14=$ recognition Arab States; $15=$ recognition Asia/Pacific; $16=$ recognition Latin America and the Caribbean; 17 = recognition Mediterranean.

field has emerged in higher education. Based on data from the IAU's (2017) International Congress Calendar (ICC), we have gathered information on inter-organisational partnerships formed through the simultaneous involvement in a vast number of initiatives, programmes and projects. $^{3}$ Figure 2 presents a visualisation of the international organisational network in higher education.

We identify a surprisingly large network made of 203 organisations, which we divided into six types and 17 issue areas (Figure 2). Our network is bimodal as it connects organisations to events (e.g. initiatives, programmes and projects), with some organisations being connected to multiple events. Our goal is to assess and visualise the inter-organisational structure of the regime.

In detail, INGOs, IGOs and university associations dominate the field quantitatively, while some IGOs, particularly UNESCO, occupy the most central roles. The network is global in its scope interlinking all world regions (except isolated North America). This inter-organisational higher education network is organised around 17 issue areas or themes (indicated by numbered squares). The densest areas of the network, the UNESCO/ NGO partnership and the Global Forum (themes 5 and 6), somewhat obscure the fact that multiple, separately coded, issue areas deal with similar questions of recognition and QAA (theme codes 7 and 9-17). Taken together, QAA issues tie together 37 organisations, while recognition issues span 55 organisations. The advantage of network visualisations is to see multiple memberships of organisations and the overlap of issue areas. For example, NGO partners and Global Forum members also participate in recognition and QAA initiatives. We now turn to these substantive issues of the regime agenda. 


\subsection{Norms: quality assurance and accreditation}

Despite earlier calls for more action in higher education quality from IOs such as the World Bank (1994), the ILO/UNESCO (1997), OECD (1999) and the European Association of Universities (2001), there was little organisational infrastructure to assure quality in higher education, both on the national and, even less, the international level. Within the last 10 years, however, this has radically changed. For example, not even the otherwise very advanced Lisbon Convention on the Recognition of Qualifications (1997), nor the so-called Bologna Process on the harmonisation of the European Higher Education Area explicitly mentioned QAA mechanisms in their initial formulations. It was only after Bologna follow-up conferences in Berlin (2003), Bergen (2005) and London (2007) that national education ministers agreed on the creation of a comprehensive QAA architecture with the European QAA network now being the densest area in our network (see Figure 2). In detail, the socalled E4 Group comprising the European Association for Quality Assurance in Higher Education (ENQA), European Students Union (ESU), European University Association (EUA) and European Association of Institutions in Higher Education (EURASHE) founded the European Quality Assurance Register for Higher Education (EQAR) in 2008. The UNESCO and the Council of Europe, supported by the European Commission, established the European Network of Information Centres (ENIC) and National Academic Recognition Information Centres (NARIC), now facilitating information at the important intersection of quality, qualification frameworks and qualification recognition (see below).

Such supranational efforts have translated into national action. The expansion of organisational infrastructure in European member states since then is impressive in speed and scope. In only a few years, 44 country-based, non-governmental QAA agencies have been created (EQAR 2017).

Parallel to the European process, all other regions have initiated similar QAA infrastructures. The Asia-Pacific Quality Network (*2003) brings together 166 member organisations, the Arab Network for Quality Assurance in Higher Education $\left({ }^{*} 2007\right)$ has to date 10 members and the Caribbean Area Network for Quality Assurance in Tertiary Education (*2004) coordinates among dozens of QAA agencies from 9 countries (ENIC-NARIC 2017).

Importantly, such regional initiatives are overarched by notable global developments. All regional bodies are part of the International Network for Quality Assurance Agencies in Higher Education (INQAA), which, established in 1991 with only 8 members, now exceeds 300 members. Similarly, UNESCO's International Association of Universities (IAU) has as one if its main objectives the promotion of higher education quality. The IAU currently has 620 university members and, since 2000, regional university associations as its members $(N=34)$ covering all world regions. In addition, thousands of universities worldwide have themselves become highly involved in QAA activities as documented in IAU's database (IAU 2017).

At the global scale, UNESCO is the main driver of QAA, leading or at least linked to all of the major international initiatives (Figure 2). Together with the OECD, UNESCO issued the milestone Guidelines on Quality Provision in Cross-border Higher Education (UNESCO/ OECD 2005) and together with the WB, it launched the Global Initiative for Quality Assurance Capacity in 2007 (GIQA; UNESCO 2016a). The GIQA figures prominently in our network analysis binding considerable chunks of the overall organisational infrastructure (Figure 2). 
Adding one more element to this markedly different era in global QAA, we highlight the growing mutual recognition and cross-national legal authority of QAA agencies. This implies, first, that local QAA agencies as well as umbrella agencies or 'meta-organizations' (Ahrne and Brunsson 2008) recognise each other. Beside the aforementioned INQAA and IAU, the US-based Council for Higher Education Accreditation (CHEA), for example, maintains an International Directory for about 467 recognised quality assurance bodies and accreditation bodies in 175 countries. For those with data on founding dates, we found that their number has more than tripled from 1996 to 2016. In their territories, these QAA agencies have accredited 44,566 higher education institutions (ISCED 4+; CHEA 2017).

In addition to such international and inter-organisational legitimacy transfers, some states now allow their higher education institutions to be accredited by a foreign or international QAA agency. U.S. accreditors, for example, offer their services in more than 65 countries (Altbach and Knight 2016). International QAA agencies such as the Accreditation Service for International Schools, Colleges and Universities (*2007) or the Foundation for International Business Administration Accreditation ( ${ }^{*} 2002$ ) have accredited hundreds of higher education institutions worldwide in the past 10 years. Many programme-based accreditors (e.g. health, engineering, business, tourism) that operate worldwide add to this complexity. The European Quality Improvement System (EQUIS) has, to date, accredited 167 higher education institutions in 41 countries worldwide (EQUIS 2017). Following a recommendation of the European Parliament and Council $(2006,61)$, European universities may now even choose multiple QAA agencies or chose 'among quality assurance or accreditation agencies in the European Register an agency which meets their needs and profile'. Currently, 20 countries recognise foreign QAA agencies from within the EU (EQAR 2014).

How has this impacted higher education institutions? Drawing on the IAU World Higher Education Dataset $(N=16,903$; ISCED $=5 A+)$, we find that $48 \%$ of all higher education institutions worldwide are accredited. Interestingly, despite obvious regional differences, accreditation prevalence differs little by size, type and age cohort (Table 1).

With the expansion and internationalisation of higher education, the rapidly growing QAA sector has, however, one major concern: the transparent definition of quality indicators and standards. We now turn to this theme on the higher education regime agenda.

Table 1. Accreditation by area, size, type and age of higher education institution (IAU WHED 2016).

\begin{tabular}{llr}
\hline & & accredited \\
\hline area & Africa & $58.1 \%$ \\
& Asia & $37.8 \%$ \\
& Eastern and Central Europe & $71.6 \%$ \\
& Middle East and Northern Africa & $53.2 \%$ \\
& North America & $79.6 \%$ \\
& Latin America and Caribbean & $25.3 \%$ \\
Size (by enrolment) & Oceania & $27.8 \%$ \\
& Western Europe & $32.1 \%$ \\
type & small & $54.5 \%$ \\
& large & $47.6 \%$ \\
founded in & public & $46.7 \%$ \\
& private & $42.1 \%$ \\
& private (religious) & $41.1 \%$ \\
& pre 1990s & $45.4 \%$ \\
\hline
\end{tabular}


Table 2. The proliferation of regional qualification frameworks (own account based on regional bodies' websites).

\begin{tabular}{llr}
\hline Year & \multicolumn{1}{c}{ Framework } & Countries \\
\hline 1997 & Southern African Development Community QF & 15 \\
2001 & Pacific QF & 15 \\
2008 & European QF & 25 \\
2010 & Transnational QF for the Virtual University of Small States of the Commonwealth & 32 \\
2012 & Caribbean QF & 15 \\
2012 & Association of Southeast Asian Nations Framework & 10 \\
2015 & Regional Higher Education Framework for East Africa & 6 \\
2015 & The Gulf QF & 6 \\
in prep. & Arab QF & Na \\
\hline
\end{tabular}

\subsection{Regulations: qualification frameworks}

Quality assurance and accreditation as a response to internationalisation and regionalisation trends in higher education is paralleled by another important process that introduces national and international standards for how to assess quality. Starting in the late 1990s in Southern Africa, all world regions have by now agreed on a qualification framework, with a group of League of Arab States member countries still negotiating the details (Table 2).

More importantly, related to these regional frameworks, is the striking proliferation of national vocational and higher education qualification frameworks (NQFs) in the past ten years. In her seminal work on the diffusion of lifelong learning and NQFs, Jakobi (2009) identified the OECD as the main driver of national policy change. Yet, it was only in the years following her work that the increase of legally-binding NQFs received a significant momentum. Our data, based on official ministry websites, shows that between 2006 and 2016 more than a hundred countries adopted NQFs, now including 120 states worldwide. If we include countries for which no date could be found and those with NQFs in preparation, the number climbs to almost 150 countries (CEDEFOP 2013) (Figure 3).

The links between QAA and NQFs are strong and run across organisational, national and international levels, which is also reflected in our network analysis (Figure 2), for example, between such organisations as ENIC and NARIC (standardisation) and ENQUA (QAA). QAA agencies rely on indicators measuring input (e.g. workload, time frame and credits) and output (e.g. level descriptors, competence definitions for learning outcomes). QFs set the standards used to accredit qualifications and to monitor assessment systems. QFs are also an important tool for QAA agencies to assess national frameworks in their compatibility with regional frameworks. As transparent and harmonised standards catalogues, QFs equip the QAA infrastructure and procedures with trust (Stensaker and Maassen 2015) - an important factor in a rapidly changing international higher education landscape awash with diploma mills and still marked by national and regional reservations about foreign standards.

\section{Integration: Towards global recognition in higher education?}

A fourth transformation concerns the striking increase in the cross-national recognition of higher education systems as structurally comparable and equivalent entities. Observers have long noted the difficulties and resistance in recognition negotiations. One of the 


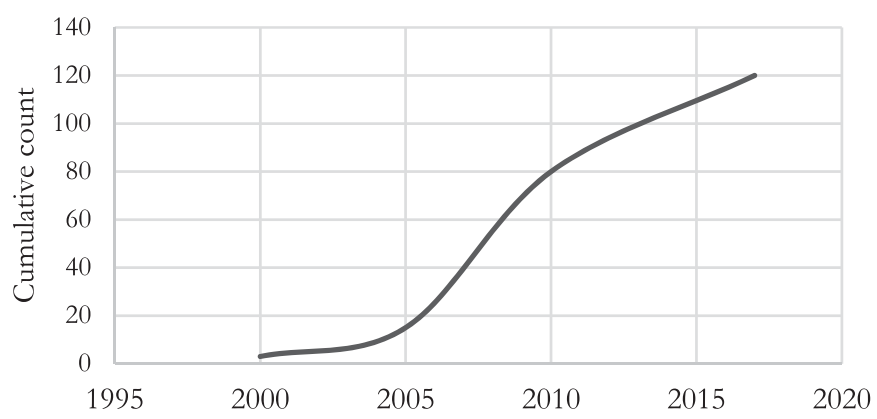

Figure 3. Cross-national adoption of national qualification frameworks (own account based on CEDEFOP 2013 and national ministries' websites).

crucial arguments in opposing international and inter-regional recognition agreements had always been uncertainty about foreign standards, the lack of quality assurance mechanisms and the gap between quality assurance and recognition (Hendriks 2005; Stensaker and Maassen 2015). Providing this missing link between QAA and recognition through the establishment of national and regional qualification frameworks has been one of the most important developments in higher education governance internationally in the past ten years and has led to a new generation of recognition agreements.

Treaties that celebrate equivalence and charter the mutual recognition of higher education qualifications have a long history (Table 3). By the early 1980s, most world areas had already formally agreed on regional recognition.

While this first generation of recognition conventions did often remain vague in formulation and weak in binding commitments, a second wave of revised conventions started in the late 1990s in all major regions, most notably in Europe, displaying some major differences.

One crucial difference reflects the growing importance of higher education worldwide. All regional conventions (except Africa) specifically refer to academic qualifications (instead of vocational qualifications). Most revised conventions also strengthen the applicant's position in recognition procedures and provide operational guidelines on how to implement the convention. They also stress the importance of a more comprehensive support structure and embeddedness in the wider context including a

Table 3. International conventions for the recognition of higher education qualifications (own account).

\begin{tabular}{llr}
\hline Year & \multicolumn{1}{c}{ Title of convention or recommendation } & N countries \\
\hline 1974 & Latin America and the Caribbean - Regional Recognition Convention & 17 \\
1976 & Mediterranean Region - Inter-Regional Recognition Convention & 12 \\
1978 & Arab States - Regional Recognition Convention & 18 \\
1979 & Europe - Regional Recognition Convention & 33 \\
1981 & African States - Regional Recognition Convention & 29 \\
1983 & Asia and the Pacific - Regional Recognition Convention & 21 \\
1997 & European Regional Convention - Lisbon Recognition Convention & 53 \\
2006 & Catania Declaration on the Euro-Mediterranean Area of Higher Education and Research & 13 \\
2008 & EU-Latin America-Caribbean Research and Higher Education Area & EU (53)+ 30 \\
2011 & Asia- Pacific Regional Convention & 9 \\
2014 & African States - Revised Regional Convention & 17 \\
\hline
\end{tabular}


strong QAA and information infrastructure, a close link to regional higher education policy and governance and the need to align with other regional and national qualification frameworks (UNESCO 2016b). In addition, some of these conventions span multiple regions, like the Euro-Mediterranean and the EU-Latin America-Caribbean agreements. Finally, the new generation of conventions include a specific reference to higher education and research implying measures to facilitate researcher mobility and international funding schemes.

Eventually, an important development is that these regional conventions could soon be overarched by a global framework. Regional bodies have long opposed a global recognition agreement and early attempts by UNESCO in the 1960s and early 1990s to design an international or even global convention were thwarted by regional opposition, particularly Europe (Hartmann 2007). With all countries and regions worldwide now committed to the standardisation and homologation of academic degrees (i.e. QFs) and the monitoring of these standards (i.e. QAA), such a global agreement seems to become more likely. Indeed, states agreed to take recognition issues more seriously as seen at the Incheon Declaration in 2015/2016 (UNESCO 2016c). More importantly, UNESCO has, in 2016, launched an initiative to draft a Global Convention on the Recognition of Higher Education Qualifications. The draft is the result of a feasibility study and multi-year intensive consultations with all member states and will be finalised for adoption in 2019 (UNESCO 2016d).

Given the strong reservations from regional bodies in the past, the draft of the Global Convention is cautious, stressing its role as complementing rather than substituting regional agreements. ${ }^{4}$ Nonetheless, its scope would be far-reaching and a breakthrough in global higher education integration. Its main objectives are, among others, to facilitate inter-regional recognition, to strengthen the link between QAA and QFs, to establish an international organisational infrastructure for recognition and to catalyse cross-border higher education policies, all adding a genuinely 'global layer' to the higher education regime.

\section{Discussion: opportunities and limits of the global higher education regime}

We have argued that rapid internationalisation requires and gradual isomorphism facilitates the emergence of a global higher education regime supported by shared sovereignties between nation states and a growing international organisational infrastructure.

The use of the regime concept helps to capture the complex architecture evolving in the environment of higher education institutions and, ultimately, around the global public good of higher education. The regime hosts various organisations located at multiple levels and pursuing diverse missions and it directs attention to its important discursive, normative and regulative pillars.

We can also specify some of the crucial regime features (Levy, Young, and Zürn 1995). Analyses suggest that the regime is moving from a tacit to an explicit regime. The complex fabric of conventions, frameworks, agreements and treaties that have taken shape at the national and international level are paralleled by increasingly formalised commitments and binding rules beyond shared expectations. Conventions themselves also become more demanding. While the first generation of regional recognition conventions, for 
example, was remote on specific duties of members, the second generation makes them discharge these very duties.

In terms of regime maturing, we argue that the higher education regime has seen a veritable boost in the past decade, taking it beyond the stage of institutional choice diagnosed for education in general (Parreira do Amaral 2010). Higher education displays a regime that has defined its themes (agenda formation) and agreed on the establishment of a regime (institutional choice) to one that is currently discussing how to implement its chosen norms and regulations (operationalisation). We have identified quality assurance and accreditation, standardisation (national and regional QFs) and recognition as the main issue areas and see manifold national and international commitments to weave governance structures together. The vast organisational infrastructure linked through national and international activities foreshadows the modes of implementation. While some regions have turned this infrastructure into an authoritative level of decision-making (e.g. the EU), other regions and the Global Convention have not yet decided on how to bring the regime to full functioning.

In general, in less than two decades, higher education has become a genuinely global discourse involving a massively expanding network of IOs and is now target of novel standards and regulations. Despite impressive organisational diversity, UNESCO is undoubtedly the focal node of this structure lending the regime a global scope. Involved in most initiatives and programmes, almost all other network members are connected to UNESCO. Research stressing the long negligence of higher education themes at UNESCO might be surprised to see such a change (Bassett and Maldonado-Maldonado 2009).

The three main issue areas of the regime - quality assurance, standardisation and recognition - are highly intertwined. With the proliferation of qualification standards, quality assurance can rely on much more transparent evaluation procedures (Stensaker and Maassen 2015). The parallel emergence of national and international/regional QFs and QAA infrastructures implies lasting institutionalisation and growing mutual trust in such an arrangement and other countries' systems, increasing the perceived and recognised educational and legal 'sameness', and now integrating 'oneness', across national systems (Meyer and Ramirez 2005).

While this article focuses on developments that indicate the rise of a global higher education regime, it shall be noted that regime intensification is not necessarily a (1) linear, irreversible and entirely unitary process nor (2) a process with a uniform impact on all actors involved, i.e. national higher education systems and individual institutions. We briefly elaborate on these important caveats.

First, regime construction implies that the expectations of involved actors converge and their willingness to share sovereignty increases. While we found many incidents that support such an observation, notable exceptions deserve attention. As an example of a thwarted attempt to introduce governance by numbers and metrics in higher education, the OECD's failure to establish its Assessment of Higher Education Learning Outcomes (AHELO) may be instructive. Inspired by successful assessments in secondary (PISA) and adult (PIAAC) literacy, the OECD run its AHELO pilot in 2012 involving 17 countries and 3 U.S. states for three disciplines (engineering, economics, generic skills). Deemed a failure by most, including the OECD's Management in Higher Education (IMHE) programme in charge of the study, AHELO has since been frozen (Altbach 2015). Indeed, 
criticism from scholars, higher education management and higher education associations was harsh, yet similar resistance had not stopped the OECD to launch and proliferate PISA (Zapp and Powell 2016). However, this time, the crucial factor for effective and legitimate global governance, i.e. a wide range of supporting countries, also seems to be the limiting factor.

While this example emphasises the limits of global higher education governance in the form of a complex mixture of technical, methodological and political problems, other challenges to the global higher education regime have their origin in the (re)surgence of antior illiberal ideologies, which often target intellectuals and higher education. A prescient example of such anti-academic policies can be found in the case of the Central European University (CEU), a private American non-for-profit university accredited in Hungary and the U.S. In 2017, the CEU was the target of a legislative amendment entailing CEU's closure, apparently retaliating for CEU's academic activities and international affiliations. As a consequence, CEU moved its operations from Budapest to Vienna in 2019 (Scholars at Risk 2019a). Other manifestations of hostile treatment of scholars and higher education institutions including violent attacks, imprisonment, limitations in freedom of speech, teaching and mobility have been regularly reported since 2014 by the recently founded Scholars at Risk (SAR) Network and their Academic Freedom Monitoring Report (SAR 2019b).

Another important observation is that regime construction has variable impact on the involved actors. The regime is emerging above a stratified and fragmented field of higher education institutions (Hazelkorn 2015; Brankovic 2018b, 2018a). Some countries and universities are likely to benefit more from the intensification of regime integration and, if not properly regulated, extant disparities might widen further. Two examples shall illustrate these risks. First, the already strong Northern skew in international student mobility might be strengthened if international degree standardisation and recognition reach inter-regional and global consensus. This implies that brain gain for Northern and Western countries and brain drain for Southern and Eastern countries would see further momentum (Choudaha and DeWit 2017).

In a similar vein, high-status (often private) universities (often situated in high-income countries) would have a competitive advantage in a global higher education field marked by common normative and regulatory frameworks, but also liberalized higher education systems. Their strong resources, attractiveness to students and researchers throughout the world and their increasingly strategic behaviour (e.g. global marketing, offshore campuses, double/triple accreditation) would give them a head start in actively availing themselves of the opportunities provided by the regime.

\section{Conclusion}

We have argued in this article that higher education worldwide is currently undergoing an important transformation. The processes we describe do not necessarily take place at the level of universities, but in their environment to which the concept of a global higher education regime as used here directs attention. New and established actors, diverse in type, mission and legislative leverage, have institutionalised a new quality in global discourse, norm and rule. Quality assurance and accreditation, qualification frameworks and recognition conventions are substantive cornerstones in this new regime architecture. The 
agenda of the regime is contested both in terms of the understanding of higher education as a primarily public or private good and in terms of the role of national sovereignty in educational policymaking (e.g. Verger 2009; Hazelkorn 2015). Yet, there seems to be a consensus that after years of aggressive (neo)liberalisation and commodification, competition and excellence, the global knowledge society needs to finally find a corrective institutional frame. The regime, as it matures, would hold new rules in order to re-embed and re-integrate higher education institutions across organisational sectors and national confines.

Lastly, despite the striking momentum, an important caveat needs to be considered. If the rise of anti-globalization and illiberal movements focuses on higher education, we may see a surge of rhetoric and policy designed to foster or revive nationally distinctive higher education systems, while undermining the key international organisations involved, most notably UNESCO. We may then witness a decline in both internationalisation and isomorphism, and thus, a stifling of the global higher education regime at its birth.

\section{Notes}

1. Own calculation based on UNESCO 2017.

2. Own calculation based on data from Cross-Border Education Research Team (2017).

3. ICC events can be filtered by keywords and contain information on date, theme, sponsors, and participants. Our dataset contains ongoing and international initiatives as described by ICC entries and as indicated by the presence of a website, board, mission and explicit member structure.

4. Current conventions do not grant the right to automatic recognition of degrees based on the wholesale recognition of systemic equivalence. This automatism is only found in multilateral treaties (e.g. between Belgium, the Netherlands and Luxembourg).

\section{Disclosure statement}

No potential conflict of interest was reported by the authors.

\section{Notes on contributors}

Mike Zapp is a postdoctoral researcher at the Institute of Education and Society at the University of Luxembourg. Current work includes cross-national studies on higher education expansion and change and the role of science in global governance.

Francisco O. Ramirez is Professor of Education and Sociology (by courtesy) at Stanford University. Curren work includes comparative studies of university organisation in the era of 'world class' rankings and cross-national research on citizenship and human rights emphases in school textbooks. Ramirez is the Director of the Scandinavian Consortium for Organizations Research at Stanford.

\section{References}

Ahrne, G., and N. Brunsson. 2008. Meta-organizations. Cheltenham: Edward Elgar.

Altbach, P. G. 2015. "AHELO: The Myth of Measurement and Comparability." International Higher Education 82: 2-3.

Altbach, P. G., and J. Knight. 2016. "The Internationalisation of Higher Education: Motivations and Realities." In Global Perspectives on Higher Education, edited by P. Altbach, 105-121. Baltimore: John Hopkins University Press. 
Anderson-Levitt, Kathryn M. 2012. "Complicating the Concept of Culture." Comparative Education 48 (4): 441-454.

Arab Network for Quality Assurance in Higher Education. 2007. "About." Accessed 30 July 2017. http://www.anqahe.org/about.html.

Asia-Pacific Quality Network. 2003. "Members." Accessed 25 July 2017. https://www.apqn.org/ members/overview.

Bassett, R. M., and A. Maldonado-Maldonado. 2009. International Organizations and Higher Education Policy: Thinking Globally, Acting Locally? New York: Routledge.

Bleiklie, I., and S. Michelsen. 2012. "Comparing Higher Education Policies in Europe Structures and Outcomes in Eight Countries." Higher Education 65 (1): 111-133.

Bollaert, L. 2014. "Quality Assurance in Europe. From Internal and Institutional to External and International." Journal of European Higher Education Area 3: 1-24.

Brankovic, J. 2018a. "How do Meta-Organizations Affect Extra-Organizational Boundaries? The Case of University Associations." In Towards Permeable Boundaries of Organizations? Research in the Sociology of Organizations, edited by L. Ringel, P. Hiller, and C. Zietsma, 259-281. Emerald Publishing Limited: Bingley.

Brankovic, J. 2018b. "The Status Games They Play: Unpacking the Dynamics of Organisational Status Competition in Higher Education." Higher Education 75 (4): 695-709.

Bromley, P. 2010. "The Rationalization of Educational Development: Scientific Activities among International Non-Governmental Organizations." Comparative Education Review 54 (4): 577-601.

Bromley, P., and D. Suarez. 2012. "Institutionalizing a Global Social Movement: Human Rights as University Knowledge." American Journal of Education 118 (3): 253-280.

Buckner, E. S. 2016. "The Changing Discourse on Higher Education and the Nation-State, 1960-2010." Higher Education 74 (3): 473-489.

CEDEFOP. 2013. "Global National Qualifications Framework Inventory." Resource document. Accessed 26 October 2016. http://www.cedefop.europa.eu/de/publications-and-resources/ publications/2211.

Chabbott, C. 2003. Constructing Education for Development: International Organizations and Education for All. New York: Routledge Falmer.

Chapman, A., and D. Pyvis. 2013. Enhancing Quality in Transnational Higher Education: Experiences of Teaching and Learning in Australian Offshore Programs. Lanham, US: Lexington Books.

Choudaha, R., and H. DeWit. 2017. "Challenges and Opportunities for Global Student Mobility in the Future: a Comparative and Critical Analysis." In Internationalisation of Higher Education and Global Mobility, edited by B. Streitwieser, 19-33. Oxford: Symposium Books.

Clark, B. R. 1983. The Higher Education System: Academic Organization in Cross-National Perspective. Berkeley, CA: University of California Press.

Council of Higher Education (CHEA). 2017. "Databases and Directories." Accessed 23 July 2017. https://www.chea.org/.

Cross-Border Education Research Team. 2017. Branch Campuses. Accessed 7 June 2018. http://cbert. org/?page_id=34.

Dale, R. 2005. "Globalisation, Knowledge Economy and Comparative Education." Comparative Education 41 (2): 117-149.

DiMaggio, P. J., and W. W. Powell. 1983. "The Iron Cage Revisited: Institutional Isomorphism and Collective Rationality." Organizational Fields American Sociological Review 48 (2): 147-160.

Dodds, A. 2008. "How Does Globalisation Interact with Higher Education? The Continuing Lack of Consensus." Comparative Education 44 (4): 505-517. doi:10.1080/03050060802481538.

Drori, G. S., J. W. Meyer, F. O. Ramirez, and E. Schofer. 2003. Science in the Modern World Polity: Institutionalization and Globalization. Stanford: Stanford University Press.

Enders, J. 2004. "Higher Education, Internationalisation and the Nation-State. Recent Developments and Challenges to Governance Theory." Higher Education 47 (3): 361-382.

ENIC-NARIC. 2017. "UNESCO Regions." Accessed 12 August 2017. http://www.enic-naric.net/unescoregions.aspx.

EQUIS. 2017. "Accredited Schools." Accessed 4 August 2017. http://www.efmd.org/accreditationmain/equis/accredited-schools. 
Espeland, W. N., and M. Sauder. 2016. Engines of Anxiety: Academic Rankings, Reputation, and Accountability. London: Sage.

European Parliament and Council. 2006. "Recommendation of the European Parliament and of the Council of 15 February 2006 on Further European Cooperation in Quality Assurance in Higher Education (2006/143/EC) Official Journal of the European Union." Accessed 13 October 2017. http://eur-lex.europa.eu/legal-content/EN/TXT/PDF/?uri=CELEX:32006H0143\&fr $\mathrm{om}=\mathrm{EN}$.

European Quality Assurance Register for Higher Education (EQUAR). 2014. “Recognising International Quality Assurance Activity in the European Higher Education Area (RIQAA)." Final Project Report. Accessed 4 August 2017. https://www.eqar.eu/fileadmin/documents/eqar/riqaa/WP5_RIQAA_ Report_final.pdf.

European Quality Assurance Register for Higher Education (EQUAR). 2017. Accessed 2 August 2017. https://www.eqar.eu/register/search.html.

European Universities Association. 2001. "Salamanca Convention 2001." Accessed 21 October 2016. http://www.eua.be/eua/jsp/en/upload/SALAMANCA_final.1069342668187.pdf.

Finnemore, M. 1993. "International Organizations as Teachers of Norms: the United Nations Educational, Scientific, and Cultural Organization and Science Policy." International Organization 47 (4): 565-597.

Frank, D. J., and J. Gabler. 2006. Reconstructing the University: Worldwide Shifts in Academia in the 20th Century. Stanford, CA: Stanford University Press.

Gunn, A., and M. Mintrom. 2013. "Global University Alliances and the Creation of Collaborative Advantage." Journal of Higher Education Policy and Management 35 (2): 179-192.

Hartmann, E. 2007. "Towards an International Regime for the Recognition of Higher Education Qualifications - The Empowered Role of UNESCO in the Emerging Global Knowledge-Based Economy." In New Arenas of Education Governance, edited by K. Martens, A. Rusconi, and K. Leuze, 76-94. New York: Palgrave.

Hazelkorn, E. 2015. Rankings and the Reshaping of Higher Education: The Battle for World-Class Excellence. Houndmills: Palgrave Macmillan.

Hendriks, B. 2005. Regional Integration Processes and Their Dynamics for External Quality Assurance: What can Other Regions Learn From the Bologna Process? International Institute for Educational Planning. Paris: UNESCO.

Hicks, D. 2012. "Performance-based University Research Funding Systems." Research Policy 41 (2): 251-261. doi:10.1016/j.respol.2011.09.007.

Hou, A. 2012. "Mutual Recognition of Quality Assurance Decisions on Higher Education Institutions in Three Regions: a Lesson for Asia." Higher Education 64 (6): 911-926.

Huisman, J., L. Meek, and F. Wood. 2007. "Institutional Diversity in Higher Education: A Cross-National and Longitudinal Analysis." Higher Education Quarterly 61 (4): 563-577.

Hwang, H. 2006. "Planning Development: Globalization and the Shifting Locus of Planning." In Globalization and Organization: World Society and Organizational Change, edited by G. S. Drori, J. W. Meyer, and H. Hwang, 69-89. Oxford: Oxford University Press.

ILO, \& UNESCO. 1997. The UNESCO Recommendation Concerning the Status of Higher-Education Teaching Personnel. Paris: UNESCO.

International Associations of Universities (IAU). 2017. "Members." Accessed 18 October 2017. http:// www.iau-aiu.net/content/organizations.

Jakobi, A. P. 2009. International Organizations and Lifelong Learning. Basingstoke: Palgrave Macmillan.

Jakobi, A. 2012. "Facilitating Transfer: International Organizations as Central Nodes for Policy Diffusion." In World Yearbook of Education, edited by G. Steiner-Khamsi, and F. Waldow, 391407. New York: Routledge.

King, R., S. Marginson, and R. Naidoo, eds. 2011. Handbook on Globalization and Higher Education. Cheltenham: Edward Elgar.

Kinser, K., D. C. Levy, J. C. Silas, A. Bernasconi, S. Slantcheva-Durst, W. Otieno, J. E. Lane, P. Praphamontripong, W. Zumeta, and R. Lasota. 2010. "Special Issue: The Global Growth of Private Higher Education." ASHE Higher Education Report 36 (3): 1-158. 
Knight, J. 2014. "Three Generations of Cross-Border Higher Education: New Developments, Issues and Challenges." In Internationalisation of Higher Education and Global Mobility, edited by B. T. Streitwieser, 43-58. Didcot, UK: Symposium Books.

Kohoutek, J. 2016. "Deconstructing Institutionalisation of the European Standards for Quality Assurance: From Instrument Mixes to Quality Cultures and Implications for International Research." Higher Education Quarterly 70 (3): 301-326.

Kosmützky, A. 2015. "In Defense of International Comparative Studies. On the Analytical and Explanatory Power of the Nation-State in International Comparative Higher Education Research." European Journal of Higher Education 5 (4): 354-370.

Kosmützky, A., and R. Putty. 2016. "Transcending Borders and Traversing Boundaries: A Systematic Review of the Literature on Transnational, Offshore, Cross-Border, and Borderless Higher Education." Journal of Studies in International Education 20 (1): 8-33.

Krasner, S. D. 1982. "Structural Causes and Regime Consequences: Regimes as Intervening Variables." International Organization 36 (2): 185-205.

Krasner, S. D. 1983. International Regimes. Ithaca: Cornell University Press.

Levy, D. C. 2006. "The Unanticipated Revolution: Private Higher Education's Global Surge." Comparative Education Review 50 (2): 217-240.

Levy, M. A., O. R. Young, and M. Zürn. 1995. "The Study of International Regimes." European Journal of International Relations 1 (3): 267-330.

Meyer, J. W., et al. 1997. "World Society and the Nation-State." American Journal of Sociology 103 (1): 144-181.

Meyer, J. W. 2006. "Foreword." In The Impact of Comparative Education Research on Institutional Theory, edited by D. Baker, and A. Wiseman, xi-xvi. Oxford: JAI Press/Elsevier.

Meyer, J. W., and D. J. Frank. 2007. "University Expansion and the Knowledge Society." Theory and Society 36: 287-311.

Meyer, J. W., and F. O. Ramirez. 2005. "Die globale Institutionalisierung der Bildung." In Weltkultur: Wie die westlichen prinzipien die Welt durchdringen, edited by J. W. Meyer and G. Mit Krücken, 212-234. Frankfurt am Main: Suhrkamp Verlag.

Mundy, K. 2007. "Educational Multilateralism - Origins and Indications for Global Governance." In New Arenas of Education Governance, edited by In K. Martens, A. Rusconi, and K. Leuze, 19-40. New York: Palgrave.

Organisation for Economic Co-Operation and Development (OECD). 1999. Quality and Internationalisation in Higher Education. Paris: OECD.

Parreira do Amaral, M. 2010. "Regime Theory and Educational Governance: The Emergence of an International Education Regime." In International Educational Governance, edited by S. K. Amos, 57-78. Emerald, UK: Bingley.

Powell, J. J. P. 2016. Barriers to Inclusion: Special Education in the United States and Germany. Abingdon: Routledge.

Powell, J. J. W., D. P. Baker, and F. Fernandez, eds. 2017. The Century of Science: The Global Triumph of the Research University. Emerald, UK: Bingley.

Ramirez, F. O., J. W. Meyer, and J. Lerch. 2016. "World Society and the Globalization of Educational Policy." The Handbook of Global Education Policy 2016: 43-63.

Ramirez, F. O., and D. Tiplic. 2014. "In Pursuit of Excellence? Discursive Patterns in European Higher Education Research." Higher Education: The International Journal of Higher Education and Educational Planning 67 (4): 439-455.

Ramirez, F. O., and C. M. Wotipka. 2001. "Slowly but Surely? The Global Expansion of Women's Participation in Science and Engineering Fields of Study, 1972-92." Sociology of Education 74 (3): 231-251.

Riddle, P. 1996. "The University and Political Authority: Historical Trends and Contemporary Possibilities." Research in Sociology of Education and Socialization 11: 43-62.

Schofer, E., and J. W. Meyer. 2005. "The Worldwide Expansion of Higher Education in the Twentieth Century." American Sociological Review 70 (6): 898-920.

Scholars at Risk. 2019a. "Central European University." Accessed 19 February 2019. https://www. scholarsatrisk.org/report/2017-04-10-central-european-university/. 
Scholars at Risk. 2019b. "Free to Think 2018." Accessed 19 February 2019. https://www.scholarsatrisk. org/resources/free-to-think-2018/.

Shin, G.-W., Y.-C. Oh, and R. J. Moon, eds. 2016. Internationalizing Higher Education in Korea. Challenges and Opportunities in Comparative Perspective. Washington: Brookings Institution Press.

Stella, A. 2006. "Quality Assurance of Cross-Border Higher Education." Quality in Higher Education 12 (3): 257-276.

Stensaker, B., and P. Maassen. 2015. "A Conceptualisation of Available Trust-Building Mechanisms for International Quality Assurance of Higher Education." Journal of Higher Education Policy and Management 37 (1): 30-40.

UNESCO. 2016a. "Global Initiative for Quality Assurance Capacity." Accessed 15 October 2016. http:// www.unesco.org/new/en/education/themes/strengthening-education-systems/highereducation/quality-assurance/giqac/.

UNESCO. 2016b. Draft Preliminary Report Concerning the Preparation of a Global Convention on the Recognition of Higher Education Qualifications. Paris: UNESCO. Accessed 28 October 2017. http:// unesdoc.unesco.org/images/0023/002347/234743E.pdfhttp://unesdoc.unesco.org/images/0023/ 002347/234743E.pdf.

UNESCO. 2016c. Incheon Declaration. http://uis.unesco.org/sites/default/files/documents/education2030-incheon-framework-for-action-implementation-of-sdg4-2016-en_2.pdf.

UNESCO. 2016d. "Global Convention on the Recognition of Higher Education Qualifications Project." Accessed 23 October 2016. http://www.unesco.org/new/en/education/themes/strengtheningeducation-systems/higher-education/recognition/global-convention-on-the-recognition-ofhigher-education-qualification-project/.

UNESCO. 2017. "Virtual University Directory." Accessed 2 October 2017. http://www.unesco.org/iiep/ virtualuniversity/linksliste.php.

UNESCO Institute of Statistics (UIS). 2018. "International Student Mobility in Tertiary Education." Accessed 18 February 2018. http://data.uis.unesco.org/Index.aspx?queryid=172.

Verger, A. 2009. "The Merchants of Education: Global Politics and the Uneven Education Liberalization Process Within the WTO." Comparative Education Review 53 (3): 379-401.

Watson, P. 2009. "Regional Themes and Global Means in Supra-National Higher Education Policy." Higher Education 58 (3): 419-438.

Wiseman, A., M. F. Astiz, and D. P. Baker. 2014. "Comparative Education Research Framed by neoInstitutional Theory: A Review of Diverse Approaches and Conflicting Assumptions." Compare: A Journal of Comparative and International Education 44 (5): 688-709.

World Bank. 1994. Higher Education. The Lessons of Experience. Washington: World Bank.

World Higher Education Database. 2016. International Association of Universities. Paris.

World Trade Organization. 2017. Accessed 16 October 2017. http://i-tip.wto.org/services/ ReportResults.aspx.

Zapp, M. 2017. "The World Bank and Education: Governing (through) Knowledge." International Journal of Educational Development 53: 1-11. doi:10.1016/j.ijedudev.2016.11.007.

Zapp, M., and C. Dahmen. 2017. "The Diffusion of Educational Ideas-An Event History Analysis of Lifelong Learning, 1990-2015." Comparative Education Review 61 (3): 492-518. doi:10.1086/692607.

Zapp, M., and J. J. W. Powell. 2016. "How to Construct an Organizational Field: Empirical Educational Research in Germany, 1995-2015." European Educational Research Journal 15 (5): 537-557. doi:10. $1177 / 1474904116641422$ 